\title{
Feeding the People, Feeding the Spirit: Revitalizing Northwest Coastal Indian Food
}

Elise Krohn and Valerie Segrest. 2010. Northwest Indian College, Bellingham, WA. Pp. $x+158$, copiously illustrated, tables, bibliography.

\author{
Reviewed by E. N. Anderson ${ }^{1}$ \\ Reviewer Address: ${ }^{1}$ Department of Anthropology, University of California, Riverside, Riverside, California 92521
}

Received: April $29^{\text {th }} 2011$

Published: August $14^{\text {th }} 2011$

This beautifully produced book is a traditional food sourcebook for Native Americans, primarily of western Washington State. Created by nutritionists working with the tribes there, it is part of a major food revitalization program that was featured at the Traditional Foods Summit at the recent Society for Applied Anthropology convention in Seattle.

The book is divided into four chapters, covering traditional views and foods; their fate in the contemporary world of supermarkets and online grocery shopping; revitalization efforts; and traditional foods-basically an ethnobotany. Many of the entries on traditional foods include myths, stories, and conservation knowledge. This is followed by a long and quite mouthwatering section of recipes. All parts of the book are useful and accessible. Anthropologists will find notably valuable the long and detailed quotes and stories from elders. Inez Bill of the Tulalip tribe contributes (on p. 42) some particularly good food rules, which from my experience seem general to the Northwest Coast and farther:

"Taking and gathering only what you need so Mother

Nature can regenerate her gifts to us."

"Remembering to not waste any of our traditional food."

"Sharing what you gather with family, friends and elders that are not able to go out and gather whenever possible."

"Including prayer and giving thanks when gathering."

"Preparing local native foods at gatherings."

"Preparing food with a good heart and mind so when you serve your meal, people will enjoy their meal."

"Providing nourishment for our people and their spirits, but also the spirit of our ancestors. We will strive to continue this way of life."
Volume2:45

(C) 2011 Society of Ethnobiology
The ethnobotany section includes not only the traditional foods that are still commonly used, but considerable food advice on how to deal with supermarket foods: how to substitute for traditional foods, how to shop wisely, what to avoid, and so on. Some of this advice is of use only to educated urban people (e.g. advice to buy nut butters other than peanut butter, p. 115), but there are now, thank goodness, a great number of highly educated and urbanized Native Northwest Coasters.

The recipes are also far from the stereotype of "hunter-gatherer" cuisine. Thanks to the importance of feasts and potlatches, the Northwest Coast peoples had a genuine haute cuisine long before the EuroAmerican world intruded. This book moves on into fusion realms: nettle pesto, wild berry crisp, balsamic blueberries with amaranth, and the like. The recipes are wonderful, and I hope to try them out soon.

In short, buy this book. It supports a good cause.

Northwest Coast food and medicine: grapevines and willow trees. Photo by E. N. Anderson, 2010.

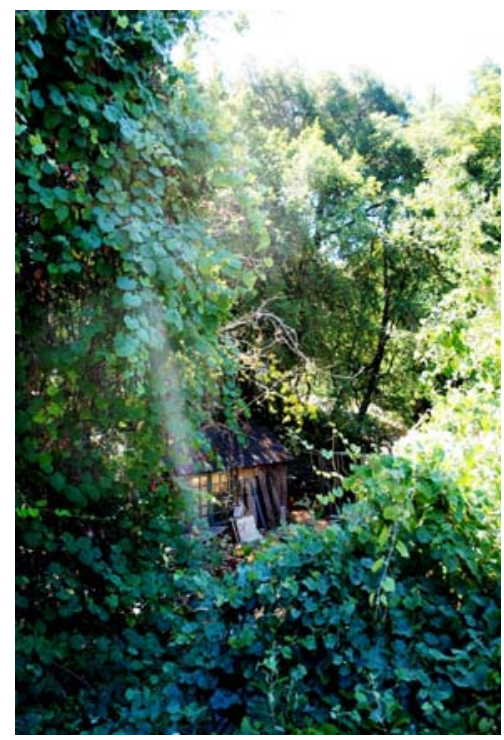

